\title{
Parts of the body in Yélî Dnye, the Papuan language of Rossel Island
}

\author{
Stephen C. Levinson \\ Max Planck Institute for Psycholinguistics, Postbus 310, 6500 AH Nijmegen, The Netherlands
}

\begin{abstract}
This paper describes the terminology used to describe parts of the body in Yéli Dnye, the Papuan language of Rossel Island (Papua New Guinea). The terms are nouns, which display complex patterns of suppletion in possessive and locative uses. Many of the terms are compounds, many unanalysable. Semantically, visible body parts divide into three main types: (i) a partonomic subsystem dividing the body into nine major parts: head, neck, two upper limbs, trunk, two upper legs, two lower legs, (ii) designated surfaces (e.g. 'lower belly'), (iii) collections of surface features ('face'), (iv) taxonomic subsystems (e.g. 'big toe' being a kind of 'toe'). With regards to (i), the lack of any designation for 'foot' or 'hand' is notable, as is the absence of a term for 'leg' as a whole (although this is a lexical not a conceptual gap, as shown by the alternate taboo vocabulary). Yélî Dnye body part terms do not have major extensions to other domains (e.g. spatial relators). Indeed, a number of the terms are clearly borrowed from outside human biology (e.g. 'wing butt' for shoulder).

(c) 2005 Elsevier Ltd. All rights reserved.
\end{abstract}

Keywords: Yélî Dnye; Papuan languages; Body part terms; Partonomy; Meronymy; Semantic fields; Taboo vocabularies

\section{The language and its speakers}

Yélî Dnye, spoken on Rossel island in the Louisiade archipelago off the east coast of New Guinea, is a so-called 'Papuan' language, i.e. non-Austronesian language of Papua New Guinea. It is an isolate, with unknown relationships to any other language, almost certainly a relict of the many languages spoken by the pre-Austronesian populations of

E-mail address: stephen.levinson@mpi.nl 
the off-shore islands of New Guinea. There are 4000 inhabitants of the island, all speakers of Yélî Dnye except for a handful of married-in spouses. There are two dialects, an eastern and a western - this description is based on the eastern dialect. English serves as the lingua franca of the province, and its currency has been increased through missionary activity since the 1950s. Quite a few Rossels speak a smattering of either Misima or Sudest, the nearest Austronesian languages. The island is remote, and there is no regular transport to the mainland, so the inhabitants are self-sufficient, with a subsistence system built on taro, bananas, sweet potato, sago and fish. The culture, although on the edges of the Massim culture area, is distinctive in many respects (Armstrong, 1928).

The language is a highly complex system at many different levels. It has the largest phoneme inventory in the Pacific with 90 phonemes, huge irregular paradigms of inflectional particles, massive verb suppletion on tense, aspect, person, negation, and other features (see Henderson, 1995; Henderson and Henderson, 1999; Levinson, in preparation). The language has strong SOV tendencies, although major phrases can occur in any order. Nominals are case-marked, and the language is strongly ergative in both case-marking and syntax. Phrase order (NPs, PPs, V complex) is fixed: demonstratives occur before the noun, but adjectives, relative clauses, postpositions after it. Verbs have prefixes which in portmanteau form indicate subject (one of nine person/number combinations), tense (one of six), aspect (one of two), negation, deictic specification, contrafactuality, and much else besides. They also have suffixes which encode in portmanteau form subject, object, tense, aspect, conditionality, etc. Because of the remoteness of the island, the terminology for parts of the body can be presumed to be autochthonous, and not reflect much influence from any other language. ${ }^{1}$

\section{Some points of general interest}

Before we get lost in the details, it is worth bringing out some of the main points of interest of the Yélî Dnye terminology for parts of the body. We will restrict ourselves to visible parts of the body (only sorcerers happily discuss the internal organs). Some special points of interest include:

- These terms are especially irregular, in the sense that many of them supplete to show locative case or possession.

- The terms imply an unusual segmentation of the body, with e.g. terms for upper and lower leg but no ordinary term for the leg as a whole, a division of the belly around the navel, and there is also no simple expression for face (and none at all for hand or foot).

- There is an alternate taboo vocabulary for use in the presence of in-laws, and this shows some higher-level grouping of ordinary language body parts.

- Body part terms are not much exploited for spatial description in the way that they are in many languages, that is, there is no extensive metaphorical extension of body part terms for spatial purposes beyond the body - spatial grams in Yélî Dnye grammaticalize from other sources.

- There is only one body part which plays an important role in affect expressions (cf. English heavy heart), namely the throat.

\footnotetext{
${ }^{1}$ Body part terminologies can be calqued without showing traces of loans, see e.g. Campbell et al., 1986.
} 
Since the relevant theoretical background and literature review is provided in the introduction to this special issue, I will postpone theoretical discussion till specific issues are raised by the data in passing.

\section{Terms for parts of the body}

\subsection{Body terms: the form classes}

The parts of the body are all denoted by nouns. Nouns in Yélî Dnye belong to a number of systems of overlapping classes. First, most nouns change their shape (have suppletive forms) when specified by a demonstrative, relative clause or when in apposition to a definite form like a proper name (there are three classes of noun distinguishable on these grounds: regular change, irregular change, no change). Second, some nouns have irregular suppletive plurals. Third, some nouns have suppletive locative forms, e.g. ntii 'sea, saltwater' (word used by both sexes) nt:ee ('sea-LOCATIVE, at sea' used by men) $\sim$ tpyele 'sea-LOCATIVE' (used by women), pée 'basket' piy:e 'in a basket', ndê 'fire' ndiya 'in the fire', chii 'the bush' $\sim d n y: i i$ 'in the bush', $p: a a$ 'village' $\sim p: o$ 'in the village, home'. Fourth, some nouns have special suppletive forms when possessed: instead of taking a possessive pronoun, as in $a p: a a$ 'my village' vs. $u$ p: $a a$ 'his village', they supplete especially in the third person possessor case, as in a tp:ee 'my son', tp:oo 'his/her son'.

Incidentally, all nouns show 2 nd person singular possession by assimilation of a nasal to the first segment of the word (sometimes with slight changes to vowel quality as indicated below), except where for phonological reasons that is inapplicable (in which case it is not marked).

Some of the body-part part terms, but not all, belong to the third and fourth classes above: that is, they supplete on locative case, or on 3rd person possession. The latter suppletion, which is shared with some kinterms (as just illustrated), might be taken to be an indication of remnants of a systematic alienable/inalienable distinction, but seems now highly selective. Suppletion on locative case does not imply suppletion on possession or vice-versa. Locative case is normally zero-marked, but precise location indicated with a spatial postposition, so suppletion here acts to highlight location, but pre-empts precise specification:

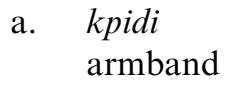
kwulo
$a$
$t: a$
'He's got $\begin{aligned} & \text { 3ContinuousAspe } \\ & \text { ProximalTense }\end{aligned}$
'He's got an armband on his arm'
(lit. 'Armband is hanging at the arm')
b. pee
$u$
mbwiye
bag his
back.LOC
wunê
$t: a$
'He's carrying a bag on his back'
$3 \mathrm{sHabCI}+\mathrm{CLOSE}$ hanging
(lit. ' A bag is habitually hanging here at his back').

The terms kwulo and mbwiye here are the locative forms of kóo 'arm' and kpadama 'back' respectively (see Table 1). As often with suppletion, it is not fully clear that the locative forms are parts of the same lexemes as the non-locative forms (e.g. mbwiye $\sim$ kpadama 
Table 1

Major simplex terms for external parts of the body

\begin{tabular}{|c|c|c|c|c|}
\hline $\begin{array}{l}\text { 1st person (preceded by } a \text { )/ } \\
\text { unmarked form }\end{array}$ & $\begin{array}{l}\text { 2nd person } \\
\text { 'your X' }\end{array}$ & $\begin{array}{l}\text { 3rd person } \\
\text { 'his X' }\end{array}$ & Locative form ${ }^{\mathrm{a}}$ & Gloss \\
\hline pââ & mââ & u pââ & $u$ mbwo 'on his trunk' & 'body, trunk' \\
\hline \multicolumn{5}{|l|}{ paa } \\
\hline mbodo & modo & (u) mbodo & $\begin{array}{l}\text { mbêmê, mbêdêma mêmê } \\
\text { 'on your head' }\end{array}$ & 'head' \\
\hline kpêmî & ngmêmî & u kpêmî & - & 'bald spot' \\
\hline$k \hat{e} \hat{e}$ & ngêê & kóó & $\begin{array}{l}\text { kwulo 'on open hand } \\
\text { or arm', kumu 'in } \\
\text { closed hand' kîl 'with } \\
\text { the hands' nkêle 'on } \\
\text { his shoulder' }\end{array}$ & 'arm/hand' \\
\hline$y i$ & $n y i$ & $y u$ & yuwo & 'lower leg/foot' \\
\hline kpââlî̀ & ngmââlî̀ & (u) kpââalî & kpââlî & 'upper leg’ \\
\hline yodo ${ }^{\mathrm{b}}$ & nyodo & yodo & kede paa $(\text { yodo p:uu })^{\mathrm{b}}$ & 'chest/front of trunk' \\
\hline \multicolumn{5}{|l|}{ (yodo pee dê $=$ breast) } \\
\hline ngmo & ngmo & (u) ngmo & - & 'breast' \\
\hline km:oo & ngm:oo & (u) km:oo & - & 'stomach/belly' \\
\hline kpadama & ngmadama & kpadama & u mbwiye & 'back' \\
\hline teknâpwo & 'neknâpwo & u teknâpwo & teknâpwo ${ }^{\mathrm{c}}$ & $\begin{array}{l}\text { 'temple (incl. sideburn } \\
\text { area, side of cheek bone)' }\end{array}$ \\
\hline 'nt:oo & 'n:oo & 'u nt:oo & - & 'clavicle' \\
\hline chópu & nуópu & u chópu & - & 'jaw (incl. chin)' \\
\hline mbwamê & mwamê & mbwamê & $\begin{array}{l}\text { mbwo 'around neck', } \\
\text { or 'on trunk' }\end{array}$ & 'neck' \\
\hline пии & пии & (u) пии & nódo & 'throat' \\
\hline ngwolo & ngwolo & ngwolo & $\begin{array}{l}\text { ngima 'in/from eye', } \\
\text { 'in sight' }\end{array}$ & 'eye' \\
\hline komo & ngomo & komo & u kwo & 'mouth' \\
\hline $\begin{array}{l}\text { kwete } \\
\text { (kwete pee dîl }=\text { lips) }\end{array}$ & ngwete & (u) kwete & - & 'lip’ \\
\hline $\begin{array}{l}\text { nyóó } \\
\text { (nyóó tii dmi= set of teeth) }\end{array}$ & nyóó & u nyóó & - & 'tooth' \\
\hline kpéngi & ngméni & u kpéngi & - & 'molar' \\
\hline 'n:uи & 'n:uu & u'n:uu & 'nuwo & 'nose’' \\
\hline 'по́ри, 'п:ии рии, & ‘nópu & u 'nópu & - & 'nostril' \\
\hline gh:aa & ng:aa & u gh:aa & - & 'hair'd \\
\hline tpoo & 'nтоo & (u) tpoo & - & 'vagina' \\
\hline$m d \hat{\imath}$ & $n m \hat{e}$ & (u) $m d \hat{e}^{\mathrm{e}}$ & - & 'penis' \\
\hline kwódo & ngwódo & (u) kwodo & kêpa & 'forehead' \\
\hline dêe & $n \hat{e} \hat{e}$ & dóó & dolo & 'tongue' \\
\hline n:iima & n:iima & u niima & - & 'navel' \\
\hline ngmââ & ngmââ & u ngmââ & - & 'armpit' \\
\hline ngwene/(ngwene yââ dê) & ngwene & ngwene & (ngwene u mênê) & 'ear' \\
\hline$n k \hat{e}$ & $n g \hat{\imath}$ & $u n k \hat{e}$ & - & 'ear drum, middle ear' \\
\hline ngópu & ngópu & u ngópu & - & 'outer ear orifice' \\
\hline pa & $m a$ & u pa & paa & $\begin{array}{l}\text { 'hip (with extension } \\
\text { to waist)' }\end{array}$ \\
\hline too & 'noo & (u) too & - & 'skin’' \\
\hline
\end{tabular}

a These locative forms also have 2nd person forms formed in the usual way with initial homorganic nasal, e.g. a kêpa 'on my forehead', ngêpa 'on your forehead'. Absence of a form in this column indicates there is no special locative form, and a locative postposition must be used.

b yodo is polysemous, or variable in extension, between chest + stomach (i.e. whole stomach area beneath ribs, in oppostion to yodo pee dê) and the area beneath ribs to navel (in opposition to m:êêu).

c Requires no locative adposition.

d As a simplex term, this is like a mass noun-it has to be specified to indicate a body part, e.g. mbodo gh:aa 'head hair'.

e Note small vowel change. 
Table 2

Major complex terms for external parts of the body

\begin{tabular}{|c|c|c|c|c|}
\hline $\begin{array}{l}\text { 1st person (preceded by } a \text { )/ } \\
\text { unmarked form }\end{array}$ & 2nd person 'your $\mathrm{X}$ ' & 3rd person 'his $\mathrm{X}$ ' & Locative form $^{\mathrm{a}}$ & Gloss and literal meaning \\
\hline kêê dópó (kn:ââ) & ngêê dópó & kóó dópó & - & 'elbow'; ' 'arm cover (base)' \\
\hline $\begin{array}{l}\text { 'n:uu kn:ââ (lit. 'wing } \\
\text { base/butt'), or nkene kn:ââ }\end{array}$ & $\begin{array}{l}\text { 'n:uu kn: } \hat{a} a ̂ \text { or } \\
\text { ngene kn:âa }\end{array}$ & $\begin{array}{l}u \text { 'n:uu kn:ââ } \\
\text { or } u \text { nkene kn: } \hat{a} \hat{a}\end{array}$ & $\begin{array}{l}\text { nkêlê 'hanging } \\
\text { on shoulder' kîgha } \\
\text { 'load on shoulder' }\end{array}$ & 'shoulder + upper arm' ; 'wing butt' \\
\hline ngmo kââ & ngmo kââ & u ngmo kââ & - & 'nipple' ; 'breast ?picture' \\
\hline m:êê yu (or m:êê vyuwo) & $m: \hat{e} \hat{e} y u$ & u m:êê $y u$ & - & $\begin{array}{l}\text { 'lower stomach (from navel to, and } \\
\text { including pubis)' }\end{array}$ \\
\hline kêê kpâpu & ngêê kpâpu & kóó kpâpu & - & 'back of hand' ; 'arm hill' \\
\hline kêê pyââ dmi & ngêê pyââ dmi & kóó pyââ dmi & - & 'fingers'; 'arm women bundle' \\
\hline kêê ndipi & ngêê ndipi & kóó ndipi & - & 'finger nail'; 'finger lid' \\
\hline kêê yodo & ngêê yodo & kóó yodo & kwulo & 'palm'; 'hand chest' \\
\hline kpââli kn:ââ & ngmââlî kn:ââ & (u) kpââlî kn:ââ & - & 'top of upper leg, pelvic joint' ; 'leg butt' \\
\hline nkêmî tp:oo & ngêmî tp:oo & u nkêmî tp:oo & - & 'uvula' ; 'green parrot little-thing' \\
\hline yi mbodo & nyimbodo & yu mbodo & - & 'knee' ; 'lower-leg head' \\
\hline kpââ pee dê & ngmââ pee dê & $u$ kpââ pee dê & - & 'cheek hollows' ; 'cheek piece dual' \\
\hline yi yodo & nyi yodo & yu yodo & - & 'sole' ; 'lower-leg chest' \\
\hline yi kpâpu & nyi kpâpu & yu kpâpu & - & 'top of foot' ; 'foot hill' \\
\hline yi pyââ dmi & nyi pyââ dmi & yu pyââ dmi & - & 'toes' ; 'leg women bundle' \\
\hline kwódo ng:oo dmi & ngwódo ng:oo dmi & (u) kwódo ng:oo dmi & - & 'face'; 'forehead ?hole bundle' \\
\hline $\begin{array}{l}k n: \hat{a} a ̂ \text { pee dê (or just } \\
k n: \hat{a} a \text { for whole) }\end{array}$ & ng:ââ pee dê & (u) kn:ââ pee dê & - & 'buttocks'; 'butt piece dual' \\
\hline mbodo gh:aa (dmi) & modo ng:aa dmi & (u) mbodo gh:aa dmi & - & 'head hair' ; \\
\hline kn:ââ puu & 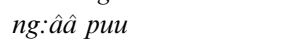 & u kn:ââ puu & - & 'anus'; 'bottom hole' \\
\hline kêe k:aa pyââ & ngêê $k: a a$ pyââ & kóó k:aa pyââ & - & 'thumb' ; ‘arm taro woman' \\
\hline yi k:aa pyââ & nyi k:aa pyââ & yu k:aa pyââ & - & 'big toe'; 'lower-leg/foot taro woman' \\
\hline kêê tpuu pyââ & ngêê tpuu pyââ & u kêê tpuu pyââ & - & 'small finger' ; 'arm/hand tail/lastborn woman' \\
\hline kn:aadi tpi & ng:aadi tpi & u kn:aadi pi & - & 'rump'; '?? handle' \\
\hline yi nd:oo dê & nyi nd:oo dê & yu nd:oo dê & - & 'ankle (bumps)'; 'foot/leg cowry dual' \\
\hline yi m: $\hat{e} \hat{e}$ & nyi m:êe & yu m:êê & - & 'calf' ; 'foot/leg biceps' \\
\hline yi dêma & nyi dêma & yu dêma & - & 'shin'; 'foot/leg ridge' \\
\hline chópu gh:aa dmi & nyópu gh:aa dmi & (u) chópu gh:aa dmi & - & 'beard' ; 'jaw hair' \\
\hline mdì gh:aaltpoo gh:aa & ngmî gh:aal'nmoo gh:aa & mdî gh:aa/u tpoo gh:aa & - & 'pubic hair'; 'penis hair'/'vagina hair' \\
\hline
\end{tabular}


Table 2 (continued)

\begin{tabular}{|c|c|c|c|c|}
\hline $\begin{array}{l}\text { 1st person (preceded by } a) / \\
\text { unmarked form }\end{array}$ & 2nd person 'your $\mathrm{X}$ ' & 3rd person 'his $X^{\prime}$ & Locative form ${ }^{\mathrm{a}}$ & Gloss and literal meaning \\
\hline vyóóma (dê) & nmyóóma (dê) & (u) vyóóma (dê) & - & 'testicle (dual)' \\
\hline tpoo pee dê & 'nтоo pee dê & tpoo pee dê & - & 'labia'; 'vagina part dual' \\
\hline mbodo kn:âa vyuwo & modo kn:ââ vyuwo & u kn:ââ vyuwo & - & 'nape'; 'head base valley' \\
\hline ngwolo w:ии & ngwolo w:ии & (u) ngwolo w:uu & - & 'eye ball/pupil'; 'eye egg' \\
\hline ngwolo pyipi dmi & ngwolo pyipi dmi & (u) ngwolo pyipi dmi & - & 'eye lash'; 'eye unravelled-rope bundle' \\
\hline yi kn:ââ & nyi kn:âa & yu kn:ââ & - & $\begin{array}{l}\text { 'back of sole, ball of foot and heel'; } \\
\text { 'lower-leg/foot base' }\end{array}$ \\
\hline kêê duwo & ngêê duwo & kóó duwo & - & 'inside of elbow' \\
\hline yi duwo & nyi duwo & yu duwo & - & 'inside of knee' \\
\hline "nt:oo vyuwo & n:oo vyuwo & u 'nt:oo vyuwo & - & 'clavicle hollows' \\
\hline kêê m:êê & ngêê m:êê & kóó m:êê & $\begin{array}{l}\text { pódu' 'around } \\
\text { upper arm' }\end{array}$ & ‘biceps’ \\
\hline yi m:êê & nyi m:êê & yu m:êê & - & 'calf muscle' \\
\hline
\end{tabular}

${ }^{a}$ These locative forms also have 2nd person forms formed in the usual way with initial homorganic nasal, e.g. $a$ kêpa 'on my forehead', ngêpa 'on your forehead' Absence of a form in this column indicates there is no special locative form, and a locative postposition must be used.

$\mathrm{b}$ This special locative form is explained by the wearing of kpidi, arm bands around the biceps, into which flowers and decorative leaves can be inserted. 
have no shared phonological material) - this is dependent on the theory of what a word is in this language.

Tables 1 and 2 give the salient body part terms: Table 1 gives the simplex (monolexemic) forms, Table 2 the complex (multi-morphemic) forms. ${ }^{2}$ Some of the forms listed as multi-morphemic are listed there because they normally collocate with a dual marker (like vyóóma dê 'testicle dual') or with a classifier. The first column gives the form occurring with a first person possessive pronoun - this is normally the unmarked form. ${ }^{3}$ The second column gives the 2 nd person singular form - as noted above, this involves the fusion of an initial homorganic nasal-I give the forms since they are not always entirely regular. The third column gives the 3rd person possessive forms, which in some cases involve a regular possessive prefix $u$-, but in other cases the possessive is marked by suppletion of the stem without $u$-. The English glosses are very approximate, and we will return to that issue below. For the complex terms in Table 2, the individual morphemes are glossed in single quotes - many of these literal meanings clearly play no compositional part in the meaning of the whole, while some morphemes have no other use or meaning ( $k n$ :aadi tpi '?? handle', i.e. 'rump').

A couple of observations: the set of simplex terms does seem to include the most salient body parts - for example all those that show clear partonomic relations (see Section 4), but there are also fairly low-level parts, like kpéngi 'molar'. Note that 'face' is complex, but then it does not seem to be a partonym of head, or to be composed of partonyms (see Section 4). Apart from kpéngi (which is a kind of nyóó 'tooth'), subordinate terms in taxonomic relations are complex (as in kêê tpuu pyââ 'hand/arm lastborn/tail woman', i.e. pinkie, which is a kind of kêe pyââ 'hand/arm woman, i.e. finger').

\subsection{Body terms: the denotational semantics}

The English glosses are inaccurate in numerous ways, for some of the Yéli Dnye terms have unusual extensions, which are sketched in Fig. 1. There is for example no ordinary ('everyday language') word for leg as a whole, the limb being divided into named parts, $y u$ ('lower leg and foot', with no separate term for 'foot') and kpââlî ('upper leg'). In a more common pattern (shared with e.g. Tzeltal, see Levinson, 1994), the term kóó for 'arm' includes 'hand', for which there is no separate term. Note here that the hand is a salient enough part that the compound kóó kpâpu (lit. 'hill of the arm/hand') denotes the back of the hand, and the three special locative forms of arm/hand denote 'on the open hand'/'in the closed hand'/'with the hands'. The trunk is segmented at the level of the navel, with a separate term for below the navel, m: $\hat{e} \hat{e} y u$ ('lower belly beneath navel down to pubis') and above it, yodo ('chest and upper belly till navel'). In addition there is no simplex term for face, instead a compound (kwódo ng:oo dmi 'forehead? hole bundle') is utilised (cf. Wegener, this volume), and the marginality of the expression is clear from the fact that it does not function as a part in the partonomy, as described below.

Fig. 1 contains a number of different kinds of information. First, there are labels, with a rough indication of extension. Secondly, there are straight lines indicating where

\footnotetext{
${ }^{2}$ I have preferred the terms simplex vs. complex to basic vs. derived in order to avoid associations with Roschian 'basic level' notions, since many 'basic level' notions are expressed in Yélî Dnye with complex forms.

${ }^{3}$ The evidence includes the fact (about to be exemplified) that the 2 nd person form is derived from the 1 st person form, not the 3rd person form, a typologically unusual pattern.
} 


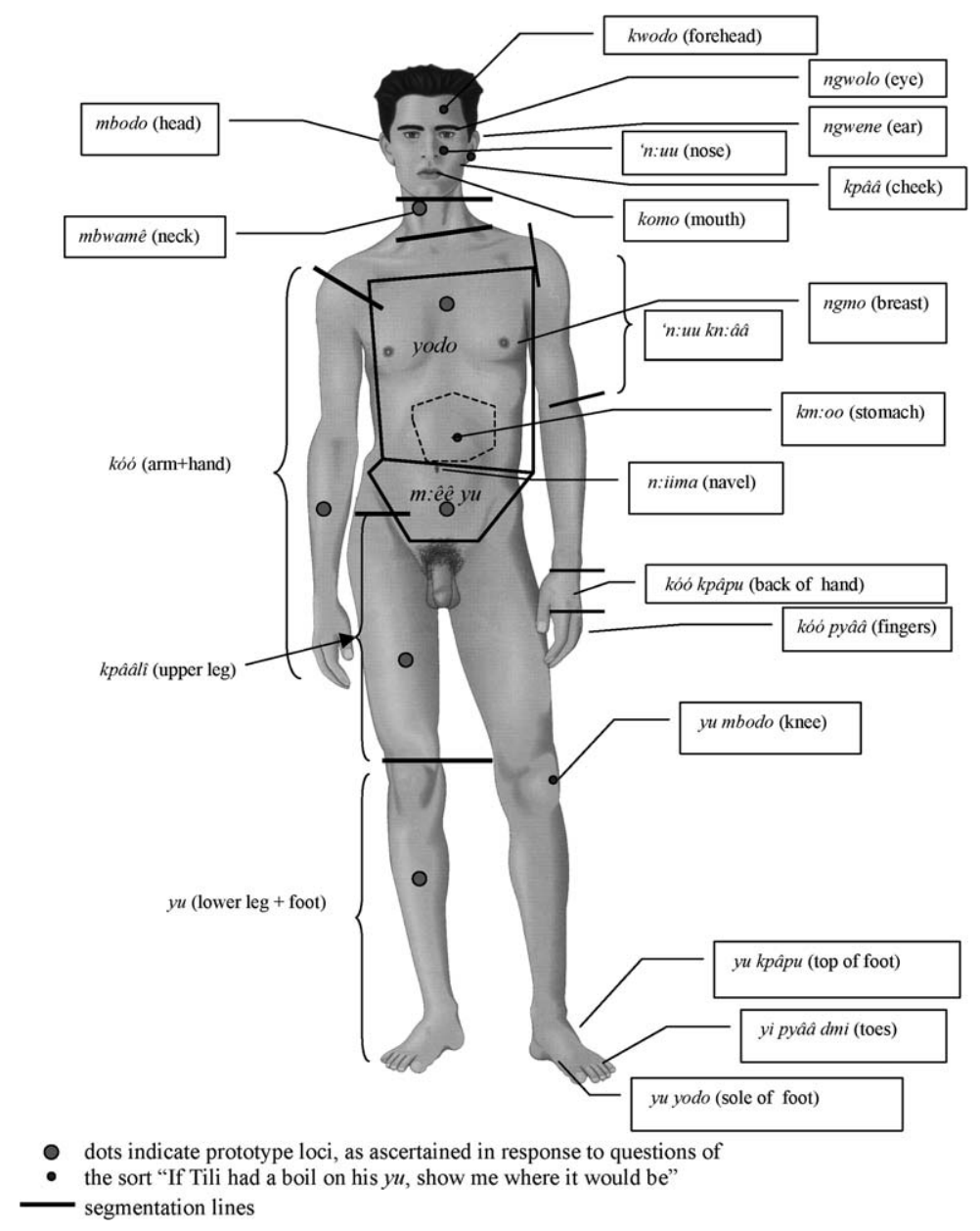

Fig. 1. Major terms for parts of the body in a male figure.

informants segmented the main parts of the body in a pencil and paper segmentation task. Thirdly, the dots indicate plausible prototypes or central areas of the category, which were obtained by stating, for example, lââ ngêê p:uu a kwo 'there's a boil (tropical ulcer) on your arm/hand', and asking the subject to indicate where he thought the speaker meant. It is interesting here to see that, by this test, the most salient area of the arm/hand is not the hand, but the forearm, and the most salient part of the lower-leg/foot is not the foot but the shin. ${ }^{4}$ Such a diagram, of course, fails to make clear if there is any systematic

\footnotetext{
${ }^{4}$ In case local knowledge about places where tropical ulcers were most likely to appear might influence this, the frame was varied ('there's a mosquito on your arm/hand'), but with similar results. Some more systematic exploration of this kind should be done though. A reviewer points out that it would be interesting to know (a) whether a large set of subjects would agree to focal points, and (b) whether these would have universal foci, as with colour terms. My investigations were done with only three informants, although they agreed very closely indeed.
} 
polysemy in terms like arm/hand. In fact, I found no clear evidence for arm/hand (or foot/ leg) polysemy, as opposed to semantic generality of the one term over the whole limb, apart from the fact (already mentioned) that kóó kpâpu 'hill of arm/hand' refers unambiguously to the back of the hand (and similarly for foot/leg, where yu kpapu refers to the top of the foot). There is definitely no fixed phrase which would pick out 'hand' or 'foot'. On the other hand, there is evidence that yodo 'chest' may also cover the whole front of the trunk, but that its extent is pragmatically circumscribed by the term for lower front (navel to pubis). A woman's breasts can be described as yodo pee dê 'chest parts two', which suggests that yodo may have polysemy of the sort (i) chest proper, (ii) whole of front of trunk - see Fig. 2 for a comparison of segmentation of the female body.

The face as a whole, as mentioned, has no simplex designation. But there are numerous named parts as shown in Fig. 3. The figure is mostly self-explanatory, but it is worth mentioning that chópu 'jaw' labels the bone and the flesh on it (Rossels kept the jawbones of their ancestors), and te knapwo '(lower) temple', the side of the eye socket, regio

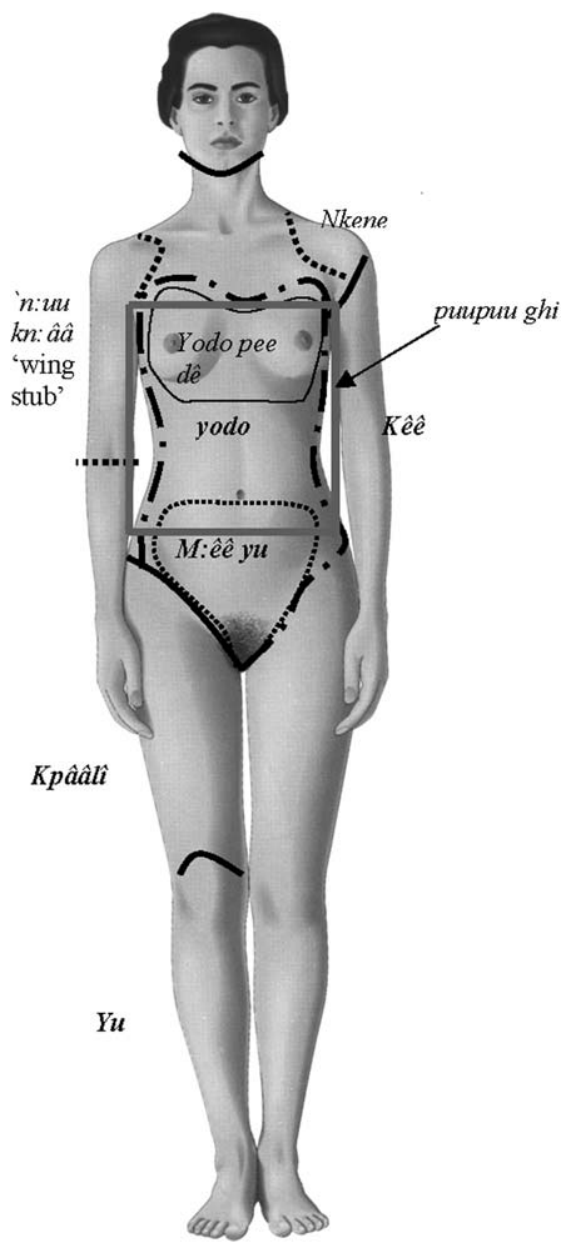

Fig. 2. Female body—some major segmentations. 


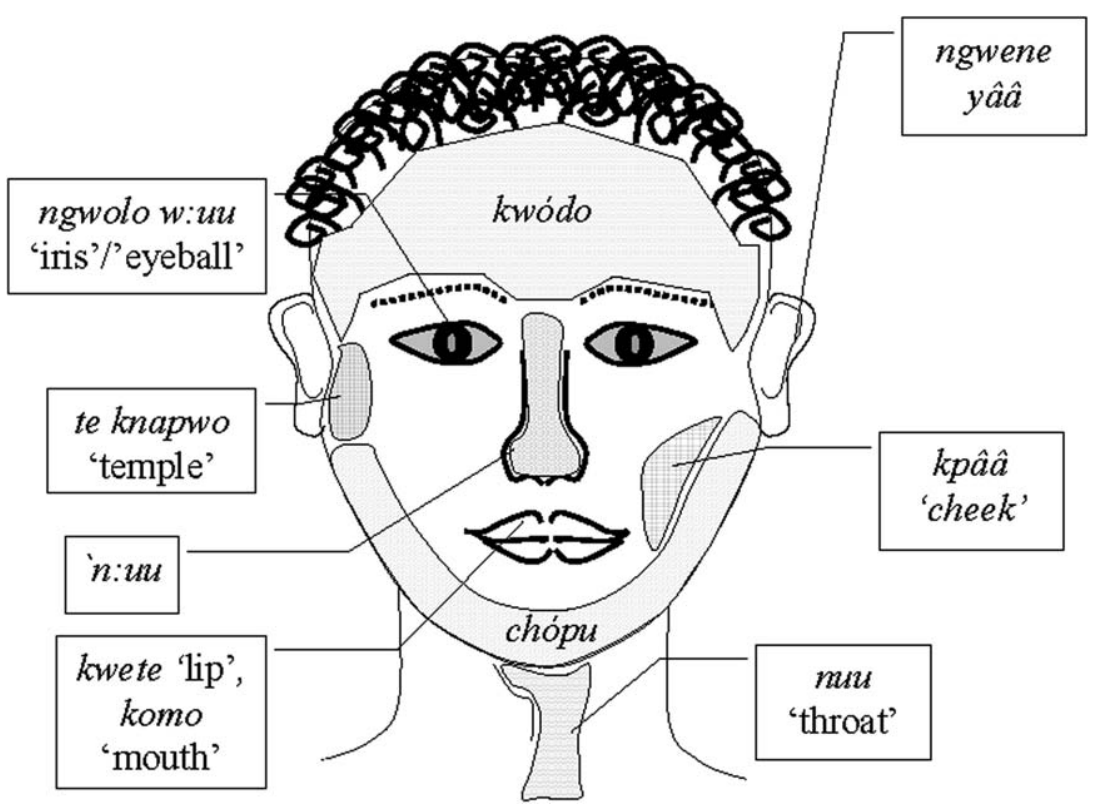

Fig. 3. Terms for parts of the face.

zygomatica. The terms kpââ ('cheek', the loose skin one can suck in), and kwete 'lip' usually collocate with the classifier pee ('piece, slice') and the dual dê, thus kwete pee dê. The term for eyeball seems to be the same as the term for iris, and means literally 'eye egg'. Note that kwódo 'forehead' has a much larger extent than the English term, covering the upper temples. Nuu 'throat' (windpipe/esophagus) is distinct from mbwamé, the term for neck.

\subsection{Compositionality in complex terms}

Yélî Dnye is a language where many important, commonly employed nominal concepts are expressed with compounds, as in tp:oo módó 'child female, i.e. daughter', $k: i i$ nt:uu 'banana fruit', and so forth. In this context, the distinction between monomorphemic and multi-morphemic body terms loses some of its significance. In the multi-morphemic terms, there is very limited compositionality, except for those terms that usually collocate with a dual and a classifier (e.g. kwete pee dê lit. 'lip piece two, i.e. lips'). A few terms, like 'n: ии рии 'nose hole, i.e. nostril', could be said to be fully compositional (although there is a frozen variant 'nupu), and a few are metaphorically motivated like yi mbodo 'leg head, i.e. knee', but these are the exception. Much more often the complex terms are opaque: thus fingers are kóó pyââ dmi lit. 'hand/arm woman bundle' (where 'bundle' is a classifier), toes are yi pyââ dmi 'lower-leg/foot woman bundle'. The parallel between finger and toes is pushed through: thumb is kóó k:aa pyââ 'arm/hand taro woman', big toe is yi k:aa pyââ 'lower-leg/foot taro woman', and so forth. The modifier kpâpu 'hill' is used for the back of the hand and the top of the foot as mentioned, while the body part yodo 'chest' as modifier 
of hand/arm denotes palm, as modifier of lower-leg/foot denotes sole. Rather than transparent compositionality, then, we find some pairing of terms across the upper and lower halves of the body.

\subsection{An alternative vocabulary: the body part terms in the taboo in-law vocabulary}

There is a taboo vocabulary to be used in the presence of in-laws, tabooed or choko kinsmen (although few people today use this - they simply avoid speaking altogether). This involves substituting special words for numerous words denoting body parts, clothing and personal possessions. Table 3 gives a good selection of these-they occur only in the 3rd person possessed form, and in many cases are derived from other words with rather unrelated meanings, following the principle of 'veiled speech' used in other ritual contexts (see Strathern, 1975). Where I know the origin I have supplied it. Although one would avoid talking at all directly to these kinsmen, if one does, the 2 nd person singular form of all the forms below simply substitutes nmyi, '2nd plural possessive' for the third person singular form $(u)$ given in Table 3.

Although Table 3 may not be complete, it is clear that many other everyday body part terms could be employed in the presence of in-laws, but these were then possessed in the 3rd person plural to show respect, e.g. yi kpadama 'their back'.

These terms might only be of antiquarian interest, except that, as often with taboo vocabularies, the terms are sometimes superordinates over the everyday language terms - that is, they conflate what are lower level terms in the everyday language (Dixon, 1971). In this case we see that, although there is no everyday term for 'genitals' (sex organs of both sexes), there is such a term in the taboo vocabulary. Similarly, we see that although there is no everyday term for 'leg' (the leg being divided into named upper and lower halves), there is a single term péépi in the taboo language which includes both halves of

Table 3

Substitute body part terms in the in-law vocabulary

\begin{tabular}{|c|c|c|}
\hline Ordinary term & Taboo vocabulary term & Gloss \\
\hline ngwolo & u chéé (dê) & 'eye' \\
\hline komo & $u$ kp:aatêdê (lit. 'his tree-cutting place') & 'mouth' \\
\hline 'n:uu & u kwodo (lit. 'his young girl') & 'nose' \\
\hline mbwodo & u njé (lit. 'his canoe rib'), locative form: njee & 'head' \\
\hline ngwene & u pééni yââ dê (lit. 'his two basket leaves'), u ché yââ dê & 'ear' \\
\hline kwódo ng:oo dmi & u ghââ ng:oo dmi & 'face' \\
\hline kóó & u kéépi & 'hand' \\
\hline kpââlî̀ & u péépi & 'upper-leg' ; 'thigh' \\
\hline yu & u péépi & 'lower-leg/foot' \\
\hline yodo & u mbwene & 'front/chest' \\
\hline nyóó tii & u kpéngima tii 'his molar-plural' (lit. 'line of persons') $u$ wóóma tii & 'teeth' \\
\hline kpââlî̀ vyuwo & u tpyodo & 'groin' \\
\hline$m d \hat{\imath}$ & u tapa 'his boulder' & 'penis' \\
\hline tpoo & u tapa 'her boulder' & 'vagina' \\
\hline ngmo & yi ntînî (dê) & 'breast' \\
\hline kóó pyââ & u kéépi pyââ & 'finger' \\
\hline yu pyââ & u péépi pyââ & 'toe' \\
\hline nkene kn:ââ & u mbw:ene kn:ââ & 'shoulder' \\
\hline mbwodo gh:aa & njé yââ vyi 'his njé (taboo word for head) leaf bunch' & 'head hair' \\
\hline
\end{tabular}


Table 4

Matched human and arboreal terms

\begin{tabular}{lll}
\hline Terms & Trees & Human bodies \\
\hline$y i$ & 'tree' & 'lower-leg + foot (not 3rd person)' \\
$k n: \hat{a} \hat{a}$ & 'stump, base' & 'buttocks, bottom' \\
pââ & 'trunk' & 'body, trunk' \\
$k p a \hat{a} l \hat{\imath}$ & 'main branches from trunk' & 'upper leg' \\
kóó & 'small branches' & 'arm/hand' \\
too & 'bark' & 'skin' \\
\hline
\end{tabular}

the leg. This removes any doubt we might reasonably have had about whether Rossels actually fail to conceive of the leg as a unitary body part.

\subsection{Body part terms across domains: lexical extensions from, rather than to, other domains}

Some of the terms employed are imported rather clearly from other domains. Thus we have, not surprisingly perhaps, kóó ndipi 'arm/hand lid, i.e. finger nail', likening the nail to a lid. More interestingly, one term for shoulder ( \pm upper arm) clearly borrows from the body part terms for feathered bipeds: ' $n: u u$ kn: âa lit. 'wing base'. 5 Still more interesting, there is a systematic match between parts for trees and parts for humans (see Table 4).

There is in addition ngwene yââ lit. 'ear leaf', i.e. ear lobe, external ear. It is far from clear that this is a mapping from human bodies to trees, given the just noted mapping from wings to human shoulders.

There are also systematic mappings of landscape terms onto the body: 'nt:oo vyuwo lit. 'clavicle valley' i.e. the hollow above the collar-bone, cf. mbodo kn: âa vyuwo 'head bottom valley', i.e. nape of neck, yu kpâpu lit. 'lower-leg/foot hill', i.e. the top of the foot, kóó kpâpu 'arm/hand hill' i.e. back of hand, yu dêma lit. 'leg hill-ridge', i.e. shin. ${ }^{6}$ (There are, incidentally, somewhat similar matching between fish and plant species, and it is possible that this parallelism constructed across natural domains is related to the totemic structure of the local belief system.)

The terms for animal body parts are essentially analogous to human parts - again with the caveat that animal parts may be the prime, not the secondary, domain: for example, pigs are very carefully cut up according to customary divisions matching the rights of feasters, and each cut is named (no pig is ever eaten out of this ritual context). Thus kn:aadi tpi, 'rump', (lit. '?? handle') has primary reference to the 7 th ranked pig part, but can also be used for the human bottom.

Pigs, dogs, reptiles and cuscus are the only quadrupeds on the island: their front legs are kóó 'arm/hand', back legs are kpââlì 'upper leg' ( $y i$ 'lower leg' is not used for a quadruped,

\footnotetext{
${ }^{5}$ Why not borrowing in the other direction, from human shoulders to wings? Because if derived from the human body part terminology, 'n:uu kn:ââ would mean 'nose base', which would be an unlikely source for the meaning 'wing'. The other way around makes perfect sense: the base of a wing is the fore-limb (shoulder) ball joint.

${ }^{6}$ Again, can we be sure of the directionality here, from landscape to human body? The landscape terms have precise and general application as simplex expressions, the body part extensions occur in complex expressions and seem ad hoc and restricted, which argues for a landscape origin (cf. mons veneris). In English, for example, no-one I think would argue that tip is primarily a body part term, on the basis of its occurrence in finger tip.
} 
e.g. a crocodile), and the terms for head, nose, etc., are as for humans. There are special terms for animal-only parts: $d p$ :ane 'horn, tusk', tpuu 'tail', 'nuиpee 'wing'. Birds are a special domain: bird beaks are called 'n:uu 'nose/beak', feathers gh: aa, 'hair/feathers', wings may be homophonous with the 'beak' word, usually though followed by classifier and dual marker: 'n:uu pee dê 'nose/beak/wing piece dual'. Feathers are denoted by the same word as hair $(g h: a a)$. The legs of birds are not divided like featherless bipeds: the lower legs are kóó dê 'arm/hands', the upper legs kpââlî ('upper legs'). Otherwise, birds are regular enough: the neck of birds is as for humans, mbwáme, tail feathers are compositional, $k n: \hat{a} \hat{a}$ gh:aa dmi, 'base hair/feathers bundle', and the divided breast is like a woman's breasts, yodo pee dê. Fish are another special domain, mapped from animals: the eyes are ngwolo, the mouth komo, the teeth nyóó, the tail fin is tpuu ('tail'), the pectoral and dorsal fins are dêê $d m i$ 'tongue bundles', gills are kpââ dmi 'cheek bundles'. However, the legs of crabs receive a specialised term, kwéti, as does the head of an octopus, nd:aa.

Contrary to the presumption in cognitive linguistics (Heine, 1997; Svorou, 1994), there is not much evidence in Yélî Dnye for the grammaticalisation of spatial grams from body part terms. The best candidate would be mbêmê, head + locative, which does function as a postposition meaning 'on the horizontal surface of' (usually with a possessive indicating its clear nominal origin), although the form mbêdema is now used primarily for the 'headlocative' sense, as in:

$\begin{array}{lllll}\text { Lamonga } & \text { mbêdêma } & \text { yinêne } & k a & k w o \\ \text { Lamonga } & \text { head-locative } & \text { flower } & \text { 3sCont.prox } & \text { standing } \\ \text { 'A flower is standing on the head of Lamonga' i.e. Lamonga is wearing a flower in } \\ \text { his hair. }\end{array}$

Mbêdêma itself has marginal uses as a postposition meaning 'on top of'. The only other body parts with generalised spatial uses seem to be paa 'waist-locative', used rarely to mean 'at the side of', and 'nuwo 'nose-locative' generalised to mean 'at the point of' (and also used as a noun meaning 'promontory'). Notably lacking from this inventory are, for example, any generalization of the 'front' or 'back' body terms into spatial vocabulary (the spatial terms are sui generis, kada 'in front, front facet', kuwó 'behind, back facet').

\section{Higher order relations between body part terms-partonomy?}

It has been generally assumed (see e.g. Anderson, 1978) that body part terms form partonomies, ${ }^{8}$ that is, the terms can be linked by 'part of' relations, so that e.g. a finger is part of a hand. But it has also been noted (e.g. in other contributions to this special issue; see also Lyons, 1977, 311ff; Brown, 2002) that there are a number of problems with natural language partonomies - for example, there are gaps and uncertainties (is a foot part of a leg?), and transitivity does not always seem to hold, or at least the partonomic inferences seem infelicitous ('A toenail is part of foot, which is part of a leg, which is part of a body,

\footnotetext{
7 A reviewer points out that, although the body part terms may not generalise to non-body spatial uses, still some spatial uses of the terms are evident in (a) the locative forms meaning 'on the back', etc., and (b) the application of some terms to generate others, presumably on a shape basis, as in 'head of lower leg, i.e. knee'.

${ }^{8}$ Some authors prefer the term meronomy - the same relation is here intended (cf. Palmer and Nicodemus, 1985, where a distinction is made).
} 


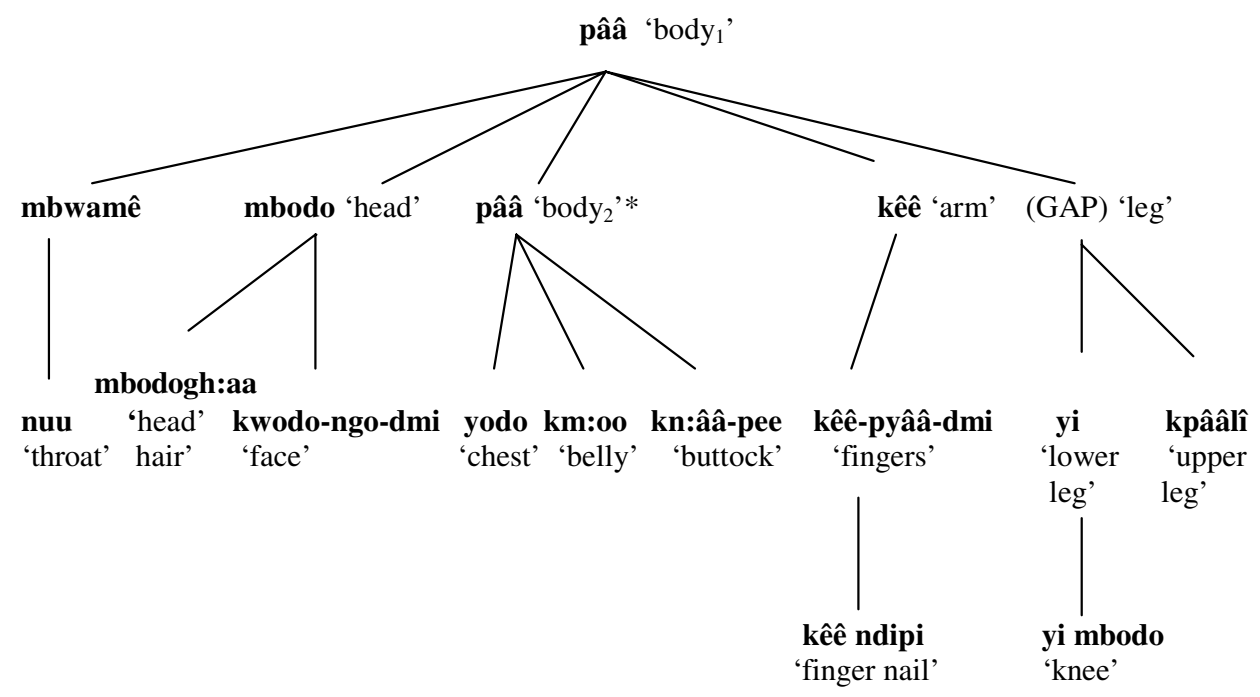

*The polysemy here is clear: it is okay to say a pââ yimo ngê da kêêlî, daa mbodo 'My body is covered in sores, but not my head'.

Fig. 4. Partial partonomy of the body, exemplifying four levels.

therefore? a toenail is part of a body' - this seems perhaps good compared to 'A handle is part of a door, a door is part of a house, therefore? a handle is part of a house').

Applying the concept of partonomy to Yélî Dnye, consultants were asked questions of the sort: ngwene, 'n:uu, ngwolo, komo, mbodo tpile dé? 'Are the ear, nose, eyes, mouth, things (i.e. part plural) of the head?' This question is perhaps less specific than the English 'Is the $x$ a part of the y?', but in any case it is the nearest idiom we can get. ${ }^{9}$ (The alternative would be to ask a spatial question: ngwene a pâa p:uu tpile? 'Is the ear attached to my body?' - on the connection between spatiality and partonomy, see Casati and Varzi, 1999).

Application of the frame question yielded statements like:
a. kêê dê pâa tpile dê
arm/hand dual body thing dual
'the two arms are two parts of the body'
b. kêê pyâa dmi kêê tpile knî
arm/hand women bundle arm/hand thing augmented
'the fingers are parts of the arm'

On this basis one might posit the partial partonomy in Fig. 4, above, with four levels of partonomy clearly attested, and a fifth level dubious. Elicitation ran into a couple of problems: first, the 'face' term is a compound (meaning literally 'forehead hole bundle'), and

\footnotetext{
${ }^{9}$ This is certainly the way to talk about parts of things, e.g. parts of a canoe. It contrasts with the way to talk about kinds of things (taxonomic relations), e.g. mbuwó 'nmo dyêêdî ngmê? 'heron bird type one?' i.e. 'Is a heron a kind of bird?'. But, in addition to this specific partonomic interpretation, it may have a broader latitude of interpretation than the English 'part of' expression, so caution is in order.
} 
consultants were unhappy to think of e.g. the mouth as part of this assemblage in the same way that the arm/hand could be said to be part of the body. This is presumably because, as suggested by the literal gloss of the face term, it is simply a collection of salient elements (forehead, mouth, eyes, etc.) and not a coherent part of the head. Even the statement 'the lips are part of the mouth' was thought dubious, possibly because the mouth is also an orifice, a negative space rather than a part (see McClure, 1975, for discussion of this point).

Second the over-arching term (or 'unique beginner'), pââ, is clearly polysemous, or at least semantically general over two readings. It is used as a classifier with far more general meaning (as in nee pââ 'canoe body, i.e. hull', yi pââ 'tree trunk, i.e. log'). In this body domain, pâa has both the meaning 'overall body' and 'trunk', just like English body. ${ }^{10}$ Curiously, the term ntóo 'dead body' seems to lack these polysemies. Still, despite these difficulties, the part terms do seem to have at least a partial partonomic organizationthat is to say, some of the terms have sense relations of a partonomic kind with other terms.

However, there are also other organization principles at work in this semantic field. For example, as mentioned above, some of the terms are clearly taxonomically related rather than partonomically related. Thus kêê k:aa pyââ 'thumb' (lit. 'arm/hand taro woman') is related to kêê pyââ dmi 'fingers' (lit. 'arm/hand women bundle, or bundle of the women of the arm/hand') by a kind of relation, not a part of relation. ${ }^{11}$ (Of course, the digit terms stand in a partonomic relation to the limb term.)

These problems, almost certainly of general cross-linguistic pertinence, raise the question whether (a) body part terms do not, in fact, all form a coherent semantic field, ${ }^{12}$ or (b) whether some other kind of semantic relation binds them after all into a coherent field. A candidate concept for (b) is topological rather than mereological, namely connectedness. ${ }^{13}$ Indeed, there have been a number of attempts to ground mereology in topology (e.g. Whitehead, 1929), which would allow the definition of part in terms of connection ( $x$ is a part of $y$ iff everything connected to $x$ is also connected to $y$-see Casati and Varzi, 1999). This weaker notion may be helpful, but it is doubtful that it would rescue us from the Yélî Dnye 'face' problem (the concept seems to be set-theoretic, a collection of elements, rather than topological). One quite plausible outcome may be that the (a) horn of the dilemma is correct: in any language, only some body part terms may form a coherent mereological field, and the best candidates will be the head, the limbs and the trunk.

\footnotetext{
${ }^{10}$ The OED offers the two senses. Here the partonomic relation between the two polysemes has to be indirectly inferred, since it takes linguistic casuistry to see sense in an elicitation question like 'Is the body part of the body?'

${ }^{11}$ Is a thumb really a kind of finger-i.e. is this relation really taxonomic? This is the standard analysis (see Levinson, 2000, p. 102). But whatever one might think about English, the composition of the Yélî Dnye expressions suggests it is: the thumb is the type of finger which is taro-like. Incidentally, a reviewer asks whether these finger expressions could be related to the custom of cutting off a girl's finger on the death of a male relative, reported elsewhere in New Guinea: the answer is that there is no ethnographic hint of this, either currently or in old descriptions like Armstrong (1928).

${ }^{12}$ Lexical semanticists (cf. Cruse, 1986) normally assume that semantic fields are structured in terms of one major type of semantic relation, and one secondary one: thus one asks "What are all the kinds of colours?", and obtains a taxonomy structured on one dimension by kind of relations ("crimson is a kind of red"), and on the other dimension by a contrast relation ("red contrasts with, or is incompatible with, green").

${ }^{13}$ Mereology is the standard term in philosophy for the study of part-whole relations - see Casati and Varzi, 1999 for the background.
} 


\section{Innards and essences, blood, sweat and tears}

Investigations into names for human internal organs are hampered by the fact that this is the domain of sorcery (and in the past, of cannibalism). Nevertheless, from the preparation of fish and game, it is clear that a number of human internal organs have common names - these are given in Table 5. Where the term is compositional, the morpheme glosses are given. A few remarks: it is not clear that there is a dedicated word for heart (kwede and gha refer to the inside, core of something), or for intestines ("nukni refers to the insides of anything). There are special terms for fat, e.g. pwaa 'solid fat of pig', d:aa 'fat of turtle', but application to persons is unsure.

Turning to bodily fluids and essences, Table 6 gives at least the common terms. It is not clear that there is a notion of soul or spirit ( $g h \hat{e} d m i$ 'breath bundle, life force' comes closest) - certainly, the essence of a person is preserved as a ghost, but there are different types of such spirits according to the mode of death (violence, sickness, drowning), and they inhabit different netherworlds. Native beliefs about procreation have the blood being contributed by the father, the skin by the mother, and the life force ( $g h \hat{e} d m i)$ from the father, who is said to give the forehead or mental strength to the child. For a matrilineal society, this is a surprising emphasis on the paternal contribution of essence.

\section{Body part terms in emotion expressions}

In many languages a few body parts, often internal organs, are held to be the seat of emotions or attitudes like fear, bravery, anger, happiness, etc. (see e.g. Enfield and Wierzbicka, 2002; Senft, 1998). In Yélî Dnye it is primarily the throat, and perhaps more broadly the neck. The absolutive form, nuи 'throat', normally collocates with positive affect, the locative

Table 5

Internal organs

\begin{tabular}{ll}
\hline Yélî Dnye term & Gloss \\
\hline nongo, nââknî & 'brains' \\
kee & 'spleen' \\
kwede & 'liver' \\
mt:eemono n:êê dêe & 'kidneys' \\
tpênê & 'lungs' \\
vyópu & 'bladder' \\
mb:eengi & 'stomach' \\
kwede? & 'heart' \\
m:êe & 'muscle of forearm or of calf' \\
mtââlî̀ & 'muscle of upper arm (biceps)' \\
mbumu w:uu & 'joint between two bones' \\
w:o & 'gums' \\
wêê $t i$ 'blood string' & 'blood vessel' \\
ngópu & 'inner ear' \\
nkêe & 'middle ear, ear-drum' \\
nkêm tp:oo & 'uvula, voice box' \\
kpadama dêma 'back bony-side' & 'spine, vertebral column' \\
dinê & podo \\
nipi & 'bone, shell' \\
\hline
\end{tabular}


Table 6

Fluids and essences

\begin{tabular}{|c|c|}
\hline Yélî Dnye term & Gloss \\
\hline$w \hat{e} \hat{e}$ & 'blood' \\
\hline kiyé & 'sweat' \\
\hline ngimi & 'tears' \\
\hline$k n \hat{e}$ & 'semen, faeces' \\
\hline 'nîp $\hat{\imath}$ & 'mucous' \\
\hline vye & 'urine' \\
\hline tpî & 'saliva' \\
\hline ghê (dmi), ghó & 'life/breath' \\
\hline$m b \hat{e} \hat{e}$ & 'puss' \\
\hline ndamê & 'placenta, afterbirth' \\
\hline
\end{tabular}

form nódo, which means both 'at the throat' and 'at the neck', collocating with both positive and negative affect. The following examples are largely self-explanatory.

(4) a. a nии $u \quad$ tpile.

my throat his/its/her thing

'A thing I really like' (lit. 'My throat its thing')

b. a nuи u kópu ngê dê pyódu my throat its word/matter ERG 3s/plImmPastPunct(preN) cause become 'I am really fond of it' (lit. 'Its thing has made my throat')

c. nmî tp:ee yoo yi nuи ghi dmi nmî nódo a tóó our3 child Pl their throat part bundle our3 neck 3HabCont sitting 'We love our children' (lit. 'Our children's throat bundles are sitting at our necks')

The 'neck' expressions can express 'choking' emotions; the neck is also a seat of knowledge - the distinction can be made purely with choice of positional verbs:
a. yi kópu
$a$
nódo
$k a$
$t: a$
that thing my neck
Cert3sContHab
hanging

'That thing is hanging at my neck, i.e. I feel bitter about it'
b. $y i$
kópu
a nódo
$k a$
tóó
that thing my
neck
Cert3sContHab
sitting

'That thing is sitting at my neck, i.e. I know all about it'
c. apê, lukwe $u$ nódo ngmê dî t:oo, he_said what his/its/her neck.LOC Indef 3snearPastCI put/touch 'The other man said: What did he do to the snake to make him angry?' (lit. 'What did he put on his neck')


Other expressions of emotion are built on gha 'core, inside', but this does not have a primary origin in the body. There may be other emotion expressions that derive ultimately from body-part expressions, for example kee 'spleen, fear':

ntii $u \quad$ kee $u$ mêne daa $\quad k w o$
sea its fear his inside NEG stands
'The fear of the sea does not stand in his inside, i.e. he has no fear of the sea'

There are also a number of unexceptional character descriptions built on mbodo 'head', as in $u$ mbodo dingîdingî, 'his head heavy, i.e. he's slow-witted'.

\section{Conclusions}

The body part terms of most cultures are influenced by diverse cross-cultural currents, from borrowed fashions of clothing or body ornament to religious beliefs about pollution (associated e.g. with the left hand or the feet). It is therefore interesting to see how an isolated island culture, largely spared such influences, treats the body as a lexical field. It has its own cultural forces, of course, including previous cannibalism (and present virtual cannibalism, namely sorcery), the exhumation of the dead and the preservation of ancestral skulls and jawbones, and traditional clothing in which only the male pubic area was covered while adult females were covered only waist to knee by grass skirts (see Armstrong, 1928).

As a partonomy, the system offers a division of the body into nine major parts: head, neck, two upper limbs, trunk, two upper legs, two lower legs. It was pointed out that the lack of a term for leg is only a lexical, not a conceptual gap, since the lexical gap is filled in the in-law taboo vocabulary (hence the unfilled node in the partonomy in Fig. 4). It may come as a surprise that in this language, not only is there no word for hand or foot, but nor is there is any easy way to designate those parts - that is, the arm/hand and foot/ lower-leg terms seem to be semantically general rather than polysemous. ${ }^{14}$

Further terms are mostly not sub-parts but rather surface features or facets (like back of hand, or knee, or front of trunk), or alternative divisions of the body (like 'wing base', shoulder plus upper arm). Surfaces can of course be organised mereologically (e.g. the top half of this page is a part of the whole), but they can also be organised in overlapping areas (so a single paragraph could lie across the division). It is far from clear that Yéli Dnye yodo, for example, is organised mereologically-inspection of Figs. 1 and 2 will show that yodo (here meaning 'top of front surface of trunk') can contrast with m:êe yu ('part of front surface of trunk below navel'), or can include it, while the breast area of a woman can be designated yodo pee dê 'two front-trunk-surfaces'. Km:oo 'stomach surface' may overlap these divisions (answers seemed imprecise).

Recognizing that some part terms like 'cheek' or 'jaw' may be surface features, possibly overlapping, helps us to understand why the Yélî Dnye 'face' term does not amount to a coherent body part, in the sense that it could be said to be part of the head, or be said to have a set of parts that exhaust the whole. Rather the 'face' term (kwódo ng:oo dmi)

\footnotetext{
${ }^{14}$ A reviewer points out that perhaps as much as a third of languages have a single 'arm/hand' term, but the status of these as polysemous vs. semantically general has not been established in most cases.
} 
denotes a collection or set of surface features (as suggested by the literal gloss 'forehead hole bundle'). The parts of the face themselves seem largely isolated on functional grounds (here cannibalism may have played a part, since victims' jawbones were preserved, and they were dispatched by crushing the windpipe). Some body part terms clearly stand in taxonomic rather than partonomic relations: e.g. a big-toe is a kind of toe, not a part of the toes.

Where do the terms come from? Major body part terms may be primary, but as pointed out, they (with the exception of head) may possibly derive from the arboreal domain. Many terms are however compounds, and these often import concepts from other domains: consider, for example, the word for eyelash, which means literally 'eye frayedrope-end bundle', or the term for big digit (thumb, big toe) formed on the word for taro, a big root. More systematically, there is some use of landscape terms (valley, hill, ridge). There is also some reuse of major part terms as modifiers of minor part terms, thus 'head lower-leg' for knee, 'chest lower-leg' for sole of foot.

Where do body part terms get exported to? Unlike in many languages, they are not (with a few exceptions) the fundamental basis of spatial expressions. Instead, they are used for animal parts, where applicable, and they are extended with inventiveness to the parts of fish. But beyond that they do not seem to have wide resonance - chiefs are not 'heads', one does not walk at the 'head' of a line, etc. The one term with major cultural resonance is the term for throat, since the throat is the seat of the emotions (at least as far as expressions of affect are concerned).

\section{Acknowledgements}

Repeated fieldwork was supported by the Max Planck Society, partly under the auspices of the ESF OMLL programme. I am grateful for comments from Asifa Majid, Nick Enfield, Gunter Senft, and Niclas Burenhult and two anonymous referees, which much improved this paper.

\section{References}

Anderson, E.S., 1978. Lexical universals of body-part terminology. In: Greenberg, J.H. (Ed.), Universals of Human Language, Word Structure, vol. 3. Stanford University Press, Stanford, pp. 335-368.

Armstrong, W.E., 1928. Rossel Island: An Ethnography. Cambridge University Press, Cambridge.

Brown, C.H., 2002. Paradigmatic relations of inclusion and identity II: Meronymy. In: Cruse, D.A., Hundnurscher, F., Job, M., Lutzeier, P.R. (Eds.), Lexicology: An International Handbook on the Nature and Structure of Words and Vocabularies, vol. 1. De Gruyter, Berlin, pp. 480-485.

Campbell, L., Kaufman, T., Smith-Stark, T., 1986. Meso-America as a linguistic area. Language 62, 530-570.

Casati, R., Varzi, A., 1999. Parts and Places. MIT, Cambridge/Boston.

Cruse, D.A., 1986. Lexical Semantics. Cambridge University Press, Cambridge.

Dixon, R.M.W., 1971. A method of semantic description. In: Steinberg, D., Jakobovits, L. (Eds.), Semantics. Cambridge University Press, Cambridge, pp. 436-471.

Enfield, N.J., Wierzbicka, A. (Eds.), 2002. The body in description of emotion: Cross-linguistic studies. Pragmatics and Cognition 10 (Special Issue).

Heine, B., 1997. Cognitive Foundations of Grammar. Oxford University Press, Oxford.

Henderson, J., 1995. Phonology and the grammar of Yele, Papua New Guinea. Pacific Linguistics, Series B-112. Henderson, J., Henderson, A., 1999. Nt:uu kópu dyuu u puku dmi (Dictionary of Rossel Language). SIL, Ukarumpa. 
Levinson, S.C., 1994. Vision, shape, and linguistic description: Tzeltal body-part terminology and object description. Linguistics 32, 791-856.

Levinson, S.C., 2000. Presumptive Meanings. MIT Press, Cambridge, MA.

Levinson, S.C., in preparation. A Grammar Of Yélî Dnye.

Lyons, J., 1977. Semantics, vol. I. Cambridge University Press, Cambridge.

McClure, E.F., 1975. Ethno-anatomy: The structure of the domain. Anthropological Linguistics 17, 78-88.

Palmer, G., Nicodemus, L., 1985. Coeur d'alene exceptions to proposed universals in anatomical nomenclature. American Ethnologist 12, 341-359.

Senft, G., 1998. Body and mind in the Trobriand islands. Ethos 26, 73-104.

Strathern, A., 1975. Veiled speech in Mount Hagen. In: Bloch, M. (Ed.), Political Language and Oratory in Traditional Societies. Academic Press, London, pp. 185-203.

Svorou, S., 1994. The Grammar of Space. Benjamins, Amsterdam.

Wegener, C., this volume. Savosavo body part terminology. In: Majid, A., Enfield, N.J., van Staden, M. (Eds.), Parts of the body: Cross-linguistic categorisation (Special Issue). Language Sciences, doi:10.1016/ j.langsci.2005.11.005.

Whitehead, A.N., 1929. Process and Reality. Macmillan, New York. 